\title{
Penerapan Pembelajaran MEA (Means-End Analysis) Berbantuan Schoology Untuk Meningkatkan Hasil Belajar Matematika
}

\author{
Satrio Wicaksono Sudarman ${ }^{1)}$, Nego Linuhung ${ }^{2)}$ \\ ${ }^{1}$ NamaFakultas Keguruan dan Ilmu Pendidikan, Universitas Muhammadiyah Metro \\ email: rio_sudarman@yahoo.com \\ ${ }^{2}$ NamaFakultas Keguruan dan Ilmu Pendidikan, Universitas Muhammadiyah Metro \\ email: nego.linuhung@ummetro.ac.id
}

\begin{abstract}
Abstrak
Rendahnya hasil belajar peserta didik, karena mengalami kesulitan dalam menyelesaikan permasalahan yang diberikan khususnya materi trigonometri serta kurangnya minat peserta didik dalam mengikuti proses pembelajaran matematika. Selain itu, guru dan peserta didik belum memanfaatkan teknologi informasi dengan maksimal, sehingga perlu usaha untuk meningkatkan hasil belajar peserta didik dengan menerapkan pembelajaran MEA (Means-End Analysis). Subjek penelitian adalah seluruh peserta didik kelas VIII SMA Negeri 1 Pekalongan Tahun Pelajaran 2018/2019. Sampel penelitian yaitu kelas XI b berjumlah 22 peserta didik. Tujuan dari penelitian tindakan kelas ini untuk mengetahui peningkatan hasil belajar peserta didik yang mendapatkan model pembelajaran MEA (Means-End Analysis) berbantuan Schoology. Berdasarkan hasil penelitian tindakan kelas dilakukan dan pembahasan yang telah diuraikan, maka dapat disimpulkan bahwa model pembelajaran MEA (Means-End Analysis) berbantuan Schoology dapat meningkatkan hasil belajar siswa kelas XI SMA Negeri 1 Pekalongan Tahun Pelajaran 2018/2019. Hasil belajar mengalami peningkatan dari prasurvei ke sikulus I dimana pada prasurvei yaitu $31,82 \%$ menjadi $45,45 \%$ pada siklus I, peserta didik yang mencapai KKM mengalami peningkatan sebesar 13,63 $\%$. pada siklus II hasil belajar peserta didik meningkat dari Siklus I yaitu 45,45\% menjadi 95,45\% pada siklus II, peserta didik yang mencapai KKM mengalami peningkatan sebesar 50\%.
\end{abstract}

Kata Kunci: Pembelajaran MEA (Means-End Analysis), Schoology, Hasil Belajar

\begin{abstract}
The low learning outcomes of students, because they have difficulty in solving the problems given, especially trigonometry material and the lack of interest of students in participating in the mathematics learning process. In addition, teachers and students have not utilized information technology optimally, so efforts are needed to improve student learning outcomes by applying MEA (Means-End Analysis) learning. The research subjects were all class VIII students of SMA Negeri 1 Pekalongan in the 2018/2019 academic year. Research sample is class XI b, which amounted to 22 students. The purpose of this classroom action research to determine the increase in learning outcomes of students who get the MEA (Means-End Analysis) learning model assisted by Schoology. Based on the results of the class action research conducted and the discussion that has been described, it can be concluded that the MEA (Means-End Analysis) learning model assisted by Schoology can improve the learning outcomes of class XI students of SMA Negeri 1 Pekalongan in the 2018/2019 Academic Year. Learning outcomes have increased from pre-survey to cycle I wherein the survey that is $31,82 \%$ to $45,45 \%$, students who are thoroughly studied have increased by $13,63 \%$. in cycle II the learning outcomes of students increased from Cycle I is 45,45\% to 95,45\%, students who have completed learning have increased by 50\%.
\end{abstract}

Keywords: learning MEA (Means-End Analysis), Schoology, learning outcomes

\section{PENDAHULUAN}

Kegiatan pembelajaran adalah suatu kegiatan yang diselenggarakan pada dunia pendidikan. Kegiatan pembelajaran adalah serangkaian proses interaksi antara guru dan peserta didik berdasarkan hubungan yang saling terkait pada keadaan ataupun suatu situasi yang 
bersifat mengedukasi guna mencapai tujuan Bersama yang diharapkan. Adanya antara guru dan peserta didik merupakan syarat yang paling utama dalam berlangsungnya suatu proses pembelajaran. Tujuan akhir dari proses pembelajaran adalah tercapainya target penguasaan materi dan suatu nilai edukatif yang disampaikan guru kepada peserta didik, dimana indikator pencapaian target tersebut yaitu hasil belajar peserta didik menjadi lebih baik atau meningkat. Dalam suatu proses pembelajaran yang terjadi dapat mengubah peserta didik yang menyangkut perubahan pada aspek pengetahuan (kognitif), aspek nilai dan sifat (afektif) dan aspek keterampilan (psikomotorik) sebagai kesimpulan akhir bahwa proses pembelajaran berhasil.

Pada suatu proses pembelajaran, mata pelajaran matematika perlu diberikan kepada semua peserta didik mulai dari sekolah tingkat taman kanak-kanak (TK) untuk membekali peserta didik dengan kemampuan matematika, yaitu diantaranya berpikir logis, analitis, sistematis, kritis dan kreatif serta kemampuan bekerja sama. Pada saat proses pembelajaran guru dalam menjelaskan materi yang disampaikan maka guru harus memilih metode atau model pembelajaran yang sesuai dengan tujuan pembelajaran yang ingin dicapai. Oleh karena itu, dalam memilih suatu metode pembelajaran harus memiliki pertimbangan seperti materi yang akan dipelajari, media yang dibutuhkan dan yang tersedia, tingkat penguasaan peserta didik, sehingga peserta didik banyak berperan aktif dalam proses pembelajaran.

Pada kenyataannya di beberapa sekolah seringkali guru yang aktif dengan teacher center, sehingga peserta didik tidak diberi kesempatan untuk aktif dalam proses belajar-mengajar. Selain itu, permasalahan yang menghambat diantaranya kemungkinan berasal dari guru yang kurang tepat dalam menggunakan metode, memanfaatkan dan menggunakan media teknologi dan informasi dalam pembelajaran di dalam kelas. Dalam upaya meningkatkan mutu pendidikan di SMA Negeri 1 Pekalongan pihak sekolah telah melakukan berbagai usaha antara lain meningkatkan kedisiplinan dalam proses kegiatan belajar mengajar dan mengikut sertakan guru dalam pelatihan. Dari instrumen penelitian yang digunakan dalam Kurikulum 2013 (K13) yaitu menggunakan Kriteria Ketuntasan Minimal (KKM), apabila belum bisa mencapai kriteria batas minimal maka peserta didik dinyatakan tidak tuntas belajar. Diperoleh hasil belajar matematika peserta didik masih cenderung rendah (belum tuntas).

Dari hasil prasurvei di SMA Negeri 1 Pekalongan terlihat bahwa tingkat pencapaian KKM belum sesuai yang diharapkan. Hal ini dapat terlihat pada data dibawah ini.

Tabel 1. Data pra survei nilai Ulangan Harian semester ganjil SMA Negeri 1 tahun pelajaran 2018/2019.

\begin{tabular}{|c|c|c|c|c|}
\hline No & Nilai KKM & $\begin{array}{c}\text { Kriteria } \\
\text { Ketuntasan }\end{array}$ & $\begin{array}{c}\text { Jumlah } \\
\text { Peserta didik }\end{array}$ & Presentase \\
\hline 1. & $\geq 70$ & Tuntas & 7 & $31,82 \%$ \\
\hline 2. & $<70$ & Tidak tuntas & 15 & $68,18 \%$ \\
\hline & Jumlah & & 22 & $100,00 \%$ \\
\hline
\end{tabular}

Berdasarkan Tabel 1, didapat bahwa hasil belajar peserta didik masih belum tuntas, yaitu jumlah peserta dengan nilai $<70$ sebesar $68,18 \%$ dan jumlah peserta didik yang nilainya mencapai $\geq 70$ hanya sebanyak $31,82 \%$. Untuk meyakinkan data pada Tabel 1 , maka dilakukan wawancara dengan guru bidang studi matematika kelas XI di SMA Negeri 1 Pekalongan tentang hasil belajar peserta didik tentang rendahnya peserta didik yang mencapai KKM. Diperoleh fakta bahwa:

1. Peserta didik cenderung kurang aktif pada proses kegiatan pembelajaran cenderung pasif karena metode pembelajaran yang dianggap kurang menarik. 
Penerapan Pembelajaran MEA (Means-End Analysis) Berbantuan Schoology Untuk Meningkatkan Hasil Belajar Matematika

Satrio Wicaksono Sudarman ${ }^{1)}$, Nego Linuhung ${ }^{2)}$

2. Belum memanfaatkan teknologi informasi untuk membantu proses pembelajaran.

3. Peserta didik kurang memperhatikan pada saat kegiatan pembelajaran langsung.

4. Pembelajaran kurang melatih peserta didik untuk berpikir secara efektif sehingga konsepkonsep trigonometri yang diajarkan sulit dipahami peserta didik.

5. Peserta didik kurang memiliki mental atau keberanian untuk bertanya atau mengutarakan pendapat dan lebih memilih bertanya kepada temannya sehingga suasana kelas menjadi kurang kondusif.

6. Terdapat banyak peserta didik yang kesulitan dalam menyimpulkan pembelajaran yang telah diberikan oleh guru.

Dari uraian berdasarkan pasurvey mengenai rendahnya hasil belajar peserta didik dan beberapa fakta yang diperoleh, secara umum peserta didik mengalami kesulitan dalam menyelesaikan soal-soal trigonometri, dan kurangnya keaktifan peserta didik terhadap pelajaran matematika, dan belum memanfaatkan teknologi informasi (e-learning) untuk membantu proses pembelajaran. Dengan demikian diperlukan usaha peningkatan hasil belajar peserta didik yaitu pembelajaran dengan menggunakan metode kooperatif diantaranya adalah dengan menggunakan pembelajaran MEA (Means-End Analysis). Pembelajaran MEA (MeansEnd Analysis) adalah salah satu pembelajaran yang dapat diterapkan pada pembelajaran matematika. Menurut Sari (2018: 90) model pembelajaran MEA (Means-Ends Analysis), peserta didik dinilai berdasarkan keaktifan peserta didik dalam proses pembelajaran.

Suyatno (2009: 66) menyatakan pembelajaran MEA (Means-End Analysis) merupakan salah satu pembelajaran dengan pemecahan masalah dengan tahap-tahap pembelajaran yaitu: menyajikan materi dengan pendekatan pemecahan masalah berbasis heuristik, elaborasi subsub masalah yang lebih sederhana, mengidentifikasi perbedaan, menyusun bagian-bagian masalah, sehingga terjadi konektivitas. Selanjutnya memilih strategi solusi dari suatu soal atau permasalahan yang diberikan. Diharapkan peserta didik merasa tertantang untuk menyelesaikan soal-soal yang diberikan. Diharapkan dengan menggunakan pembelajaran $M E A$ (Means-End Analysis) berbantuan Schoology ini terjadi peningkatan hasil belajar yang lebih baik. Menurut Harto, dkk. (2014) karakteristik Model Pembelajaran MEA (Means-End Analysis) yaitu: 1) pada proses pembelajaran peserta didik dihadapkan langsung pada permasalahan dan peserta didik diberikan keleluasaan dalam menggali dan menyelidiki masalah. Peserta didik menganalisis permasalahan yang ditemukan kemudian mencari cara pemecahan masalahnya secara berkelompok; 2) interaksi yang terjadi dalam kelompok berdampak pengiring yang akan sangat membantu peserta didik dalam menginvestigasi permasalahan matematika yang dihadapi peserta didik; selanjutnya 3) guru berperan sebagai fasilitator, dengan memberikan soal atau masalah yang berkaitan dengan kehidupan seharihari, serta membimbing peserta didik melakukan penyelidikan terhadap permasalahan, pada akhirnya peserta didik menemukan pemecahan masalah yang dihadapi.

Sejalan dengan pendapat tersebut, Nurafiah (2013) mengemukakan karakteristik Model Pembelajaran MEA (Means-End Analysis) yaitu: 1) pada penerapan model pembelajaran MEA (Means-End Analysis), penilaian peserta didik bukan hanya berdasarkan hasil saja, tetapi dapat dinilai berdasarkan proses pengerjaan; 2) Peserta didik juga dituntut agar dapat memahami apa tujuan yang hendak dicapai atau masalah apa yang hendak diselesaikan; 3) model pembelajaran ini lebih memusatkan peserta didik pada perbedaan antara pernyataan sekarang (the current state of the problem) dengan tujuan yang hendak dicapai (the goal state). Kelebihan dari model pembelajaran MEA (Means-End Analysis) menurut Oktavia dan Suprayitno (2017: 1158) berdasarkan indikator peserta didik dapat terbiasa memecahkan atau menyelesaikan soal-soal 
pemecahan masalah, peserta didik berpartisipasi lebih aktif dalam pembelajaran dengan seringnya mengekspresikan idenya.

Adapun langkah-langkah Model Pembelajaran MEA (Means-End Analysis) menurut beberapa ahli, antara lain menurut Huda (2014: 296-297) tahap-tahap model pembelajaran MEA (Means-End Analysis) sebagai berikut: 1) guru menyajikan materi dengan pendekatan masalah berbasis heuristik; 2) Guru mendeskripsikan hasil atau tujuan yang diinginkan; 3) Peserta didik mengelaborasi kondisi-kondisi yang dibutuhkan untuk mencapai tujuan akhir (end state); 4) Peserta didik membuat submasalah-submasalah, merinci masalah yang lebih sederhana; 5) Peserta didik mendeskripsikan kondisi terkini berdasarkan submasalahsubmasalah tersebut; 6) Peserta didik mengidentifikasi perbedaan-perbedaan dan menyusun submasalah-submasalah agar terjadi konektivitas; kemudian 7) peserta didik menganalisis (analyze) cara-cara (means) yang dibutuhkan; 8) mengkonstruksi dan menerapkan rencana; 10) memilih strategi solutif yang paling mungkin untuk memecahkan masalah yang sama; dan terakhir; 11) melakukan review dan evaluasi.

Beberapa penelitian yang telah dilakukan menerapkan pembelajaran MEA (Means-End Analysis) yaitu: (Juniyarti, 2014), (Riana, 2017), (Prihatiningtyas \& Nurhayati, 2017), (Nugroho, dkk. 2017), dan (Mukhlason, 2019), model pembelajaran MEA (Means-End Analysis) memberikan dampak positif terhadap hasil belajar pada beberapa bidang ilmu, namun jika melihat hasil yang diperoleh pembelajaran MEA (Means-End Analysis) belum memberikan hasil yang maksimal, pembelajaran MEA (Means-End Analysis) dapat berjalan dengan baik jika di kolaborasi dengan pemanfaatan teknologi, sebab pada era revolusi 4.0 peserta didik dituntut untuk mampu memanfaatkan teknologi sehingga peserta didik memiliki literasi teknologi yang lebih baik.

Guna penunjang langkah-langkah pada pembelajaran MEA (Means-End Analysis) dalam penelitian ini memanfaatkan e-learning berbantuan Schoology. Kelebihan Schoology menurut Purwaningsih, dkk. (2017: 52) menggabungkan fitur jejaring sosial dengan Learning Management System ( LMS), sehingga dapat berinteraksi sosial sekaligus belajar. Schoology sangat menunjang kolaborasi berbagai data individu, kelompok, dan diskusi kelas, sehingga Schoology sangat cocok digunakan sebagai media pembelajaran pendukung dalam $e$-learning. Beberapa penelitian yang telah dilakukan dalam menerapkan Schoology yaitu (Aminoto \& Pathoni) (Widiantoro \& Rakhmawati, 2015), dan (Murni, 2016), dan (Supratman \& Purwaningtias, 2018), penelitian derfokus pada penerapan media e-learning berbasis Schoology untuk meningkatkan hasil belajar pada berbagai disiplin ilmu namun belum fokus pada hasil belajar matematika dan belum mengkombinasikan Schoology dengan metode pembelajaran dalam penelitian ini ada (Means-End Analysis) berbantuan Schoology.

Berdasarkan pendahuluan yang telah diuraikan tujuan dari penelitian tindakan kelas ini adalah untuk memperoleh gambaran nyata bagaimana model pembelajaran MEA (Means-End Analysis) berbantuan Schoology yang diterapkan di kelas dan mengetahui peningkatan hasil belajar peserta didik yang mendapatkan model pembelajaran MEA (Means-End Analysis) berbantuan Schoology.

\section{METODE PENELITIAN}

Pada penelitian ini, jenis penelitian yang digunakan adalah Penelitian Tindakan Kelas (PTK) yaitu guru melakukan kegiatan pembelajaran di dalam kelas dengan menerapkan model pembelajaran MEA (Means-End Analysis) untuk meningkatkan hasil belajar. Subjek penelitian adalah seluruh peserta didik kelas VIII SMA Negeri 1 Pekalongan Tahun Pelajaran 2018/2019, sebanyak 240 peserta didik. Kelas yang diambil menjadi sampel penelitian adalah kelas XI b. Dari kelas yang ada diambil satu kelas untuk diteliti, kelas yang diambil yaitu kelas XI b yang berjumlah 22 peserta didik. 
Penerapan Pembelajaran MEA (Means-End Analysis) Berbantuan Schoology Untuk Meningkatkan Hasil Belajar Matematika

Satrio Wicaksono Sudarman ${ }^{1)}$, Nego Linuhung ${ }^{2)}$

Pada penelitian ini, siklus penelitian tindakan kelas yang digunakan adalah menurut Trianto (2011: 30) yaitu menggunakan sistem spiral merefleksi diri yang terbagi ke dalam beberapa siklus, meliputi tahapan perencanaan (planning), pelaksanaan (action), pengamatan (observation), refleksi (reflection) dan kembali ke perencanaan yang merupakan dasar untuk suatu ancang-ancang pemecahan permasalahan. Tes berupa soal uraian dengan materi Trigonometri sebanyak 5 butir dengan alokasi waktu 70 menit pada aspek kognitif. Alat ukur yang digunakan untuk mengukur hasil belajar, maka perlu diketahui tingkat validitas dan reliabilitas terlebih dahulu. Validitas menurut Arikunto (2013:168) yaitu suatu instrumen yang valid dan sahih mempunyai validitas yang tinggi, sebaliknya instrumen yang kurang valid berarti memiliki validitas yang rendah, sejalan dengan itu menurut Sukardi (2012: 43) suatu instrumen penelitian dikatakan mempunyai nilai yang tinggi, apabila tes yang dibuat mempunyai hasil yang konsisten dalam mengukur yang hendak diukur dalam penelitian ini hasil belajar.

\section{HASIL DAN PEMBAHASAN}

Penelitian ini menggunakan penelitian tindakan kelas (PTK) yang dilaksanakan dalam dua siklus, pada siklus 1, terdiri dari 3 kali pertemuan penerapan MEA (Means-End Analysis) dan 1 kali tes akhir siklus 1, sedangkan pada siklus 2, terdiri dari 4 kali pertemuan penerapan MEA (Means-End Analysis) dan 1 kali tes akhir siklus 2. Pada siklus I tahap-tahapan PTK yaitu terdiri dari: perencanaan, pelaksanaan tindakan, observasi, dan refleksi. Data hasil belajar peserta didik setelah dilakukan tindakan kelas dengan menggunakan model pembelajaran $M E A$ (Means-End Analysis) berbantuan Schoology pada siklus I dapat dilihat pada Tabel 2 berikut:

Tabel 2. Hasil Tes akhir Peserta didik Menyelesaikan Soal Pada Siklus I

\begin{tabular}{|c|c|c|c|c|}
\hline No & Nilai KKM & Kriteria Ketuntasan & Jumlah & Persentase \\
\hline 1 & $\geq 70$ & Tuntas & 10 & $45,45 \%$ \\
\hline 2 & $<70$ & Tidak tuntas & 12 & $54,55 \%$ \\
\hline & \multicolumn{2}{|c|}{ Jumlah } & 22 & $100,00 \%$ \\
\hline
\end{tabular}

Berdasarkan Tabel 2 peserta didik yang memperoleh nilai $\geq 70$ atau dikategorikan mencapai ketuntasan belajar adalah sebanyak 10 siwa atau (45,45\%), sedangkan peserta didik yang belum mencapai ketuntasan belajar dalam pembelajaran atau nilai $\leq 70$ sebanyak 12 orang atau $(54,55 \%)$.

Refleksi Siklus I, dilihat dari hasil observasi peserta didik didapat persentase aktivitas tiap-tiap indikator pada siklus I masih perlu ditingkatkan lagi. Dan hasil belajar peserta didik yang masuk dalam kategori tuntas belajar adalah 54,55\%. Hasil refleksi pada siklus I menunjukkan:

1) Masih terdapat peserta didik yang tidak memperhatikan pada saat guru menerangkan.

2) Tidak semua peserta didik mencatat hal yang diperoleh pada saat pembelajaran.

3) Peserta didik kurang antusias untuk bertanya tentang sesuatu yang belum dipahami ketika guru memberikan kesempatan untuk bertanya namun ini sudah mencapai taarget yang diharapkan.

4) Masih terdapat peserta didik yang kurang memahami materi dan pemahaman model pembelajaran MEA (Means-End Analysis) berbantuan Schoology, sehingga pada saat presentasi kurang interaktif.

Untuk mengatasi keadaan tersebut peneliti melakukan: 
1) Guru mengkaitkan materi pelajaran matematika dengan kehidupan sehari-hari, untuk memotivasi peserta didik agar memperhatikan pada saat guru menjelaskan materi pelajaran.

2) Menekankan kepada semua peserta didik agar mencatat apa yang diperoleh pada saat pembelajaran, dan memberikan penilaian bagi peserta didik yang memiliki rangkuman dari seluruh proses pembelajaran.

3) Memberikan pertanyaan-pertanyaan yang memancing, sehingga peserta didik akan termotivasi untuk bertanya.

4) Penguasaan kelas perlu ditingkatkan agar suasana kelas tidak begitu ramai dan bisa kondusif terutama pada saat diskusi mengerjakan tugas dengan pasangannya.

Setelah diadakan refleksi pada siklus I maka dilanjutkan pada tahap siklus II. Tahap-tahap pembelajaran pada siklus II sama seperti yang telah dilakukan pada siklus I yaitu: perencanaan, pelaksanaan tindakan, observasi, dan refleksi. Setelah Tindakan dan observasi pada siklus II selesai maka diadakan refleksi untuk melihat perkembangan dari hasil belajar peserta didik. Dari refleksi didapat bahwa aktivitas peserta didik dan hasil belajar peserta didik telah meningkat dan telah sesuai dengan indikator yang diinginkan. Meskipun hasil belajar masih belum maksimal, metode yang digunakan dalam tindakan ini sudah menunjukan dapat meningkatkan hasil belajar peserta didik sehingga tidak dilakukan perencanaan ulang karena hasil yang diinginkan telah tercapai

Pada penelitian ini, hasil belajar merupakan nilai yang diperoleh peserta didik dari suatu tindak belajar pada akhir proses pembelajaran peserta didik. Berdasarkan hasil penelitian yang telah dilakukan diperoleh skor hasil belajar peserta didik dalam proses pembelajaran matematika pada materi triginometri dengan menerapkan metode MEA (Means-End Analysis) berbantuan Schoology pada siklus I dan II disajikan pada Tabel 3 berikut ini:

Tabel 3. Data Hasil Belajar Peserta Didik pada Siklus I dan Siklus II

\begin{tabular}{|c|c|c|c|c|c|c|c|c|}
\hline \multirow[b]{2}{*}{ No } & \multirow{2}{*}{$\begin{array}{c}\text { Kategori } \\
\text { Ketuntasan }\end{array}$} & \multirow{2}{*}{$\begin{array}{l}\text { Nilai } \\
\text { KKM }\end{array}$} & \multicolumn{3}{|c|}{ Banyak Peserta didik } & \multicolumn{3}{|c|}{ Presentase } \\
\hline & & & $\begin{array}{c}\text { Pra } \\
\text { Siklus }\end{array}$ & $\begin{array}{l}\text { Siklus } \\
\text { I }\end{array}$ & $\begin{array}{l}\text { Siklus } \\
\text { II }\end{array}$ & Pra Siklus & Siklus I & Siklus II \\
\hline 1 & Tuntas & $\geq 70$ & 7 & 10 & 21 & $31,82 \%$ & $45,45 \%$ & $95,45 \%$ \\
\hline 2 & Tidak tuntas & $<70$ & 15 & 12 & 3 & $68,18 \%$ & $54,55 \%$ & $4,55 \%$ \\
\hline \multicolumn{3}{|c|}{ Jumlah } & 22 & 22 & 22 & $100 \%$ & $100 \%$ & $100 \%$ \\
\hline
\end{tabular}

Berdasarkan Tabel 3, diperoleh hasil belajar peserta didik pada pra siklus yang belum mencapai nilai KKM yaitu sebanyak 15 peserta didik atau $68,18 \%$, sedangkan peserta didik yang tuntas mencapai nilai $K K M \geq 70$ yaitu sebanyak 7 peserta didik atau $31,82 \%$. Pada siklus I peserta didik yang belum mencapai ketuntasan belajar yaitu sebanyak 12 peserta didik atau $54,55 \%$, sedangkan peserta didik yang tuntas mencapai nilai $\mathrm{KKM} \geq 70$ yaitu sebanyak 10 peserta didik atau 45,45\%, hal ini berarti peserta didik belum mencapai indikator yang peneliti tetapkan yaitu $75 \%$ peserta didik yang mendapat nilai $\geq 70$. Kemudian pada siklus II peserta didik yang belum mencapai nilai KKM sebanyak 1 peserta didik atau 4,55\%, sedangkan peserta didik yang sudah tuntas mencapai nilai $K K M \geq 70$ sebanyak 21 peserta didik atau 95,45\%. 
Penerapan Pembelajaran MEA (Means-End Analysis) Berbantuan Schoology Untuk Meningkatkan Hasil Belajar Matematika

Satrio Wicaksono Sudarman ${ }^{1)}$, Nego Linuhung ${ }^{2)}$

Selanjutnya ditampilkan peningkatan peserta didik yang telah mencapai KKM dan yang belum mencapai KKM pada setiap siklus, seperti pada Gambar 1 berikut:

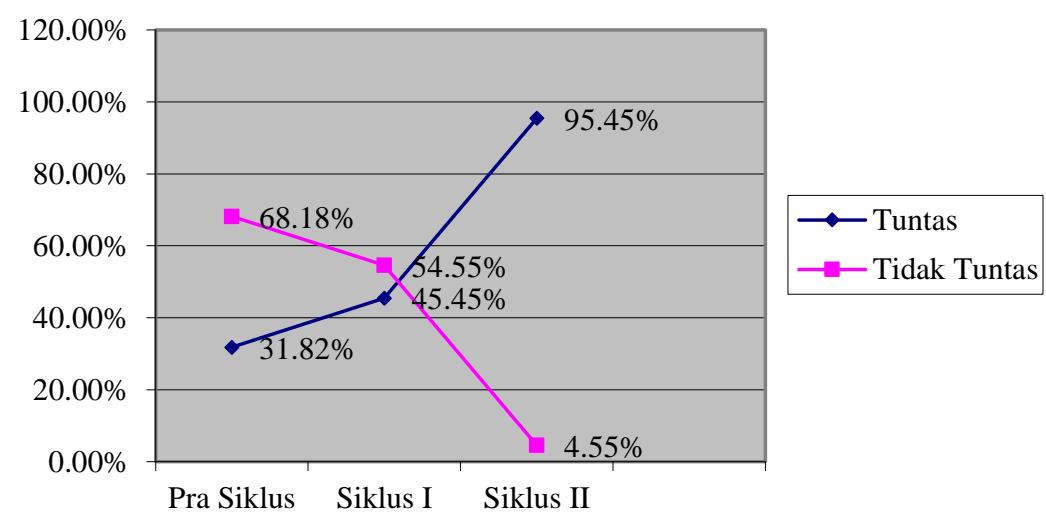

Gambar 1. Grafik Jumlah Peserta Didik yang Mencapai KKM Pada Setiap Siklus

Berdasarkan Gambar 1, menunjukkan bahwa ada peningkatan dari prasurvei ke siklus I dimana pada prasurvei yaitu $31,82 \%$ menjadi $45,45 \%$ pada siklus I. peserta didik yang mencapai KKM mengalami peningkatan sebesar $13,63 \%$. Kemudian pada siklus II hasil belajar peserta didik meningkat dari Siklus I yaitu 45,45\% menjadi 95,45\% pada siklus II, peserta didik yang telah mencapai KKM mengalami peningkatan sebesar $50 \%$.

Pada siklus I, proses pembelajaran peserta didik terkesan kurang berani dan masih agak takut untuk menjadi pemeran dalam menyampaikan ringkasan materi. Selain itu, masih banyak peserta didik yang kurang percaya diri, malu dan takut untuk bertanya kepada guru dan mempresentasikan hasil kelompok di depan kelas. Berdasarkan beberapa kekurangan pada siklus I di atas pembelajaran masih belum efektif maka berpengaruh terhadap hasil belajar peserta didik. Pada siklus II, tahapan-tahapan pelaksanaan pembelajaran sudah direfleksi sehingga sudah dengan persiapan yang lebih baik daripada siklus sebelumnya.

Berdasarkan hasil pembelajaran pada siklus II, peningkatan terjadi karena dalam proses pembelajaran setiap peserta didik dapat terlibat aktif dalam interaksi dengan guru dan peserta didik lain, sehingga peserta didik tidak lagi bersifat pasif dan dapat berkolaborasi antar peserta didik. Temuan ini mendukung (Nugroho dkk., 2017) bahwa pembelajaran MEA (Means-End Analysis) dirancang untuk pembelajaran matematika serta penelitian (Pratiwi, 2016) dan Saraswati (2018) dimana pembelajaran MEA (Means-End Analysis) dapat melatih peserta didik menyelesaikan soal-soal pemecahan masalah, serta mendapat banyak pengalaman melalui kolaboratif.

Penerapan pembelajaran MEA (Means-End Analysis) berbantuan Schoology ini akan memberikan pengaruh terhadap proses belajar karena pembelajaran MEA (Means-End Analysis) berbantuan Schoology memberikan keterampilan peserta didik untuk bertanya, dan memanfaatkan tekhnologi untuk mencari sumber belajar, dan peserta didik menjadi tertarik untuk mengikuti apa yang disampaikan guru, peserta didik menjadi memliki keberanian untuk mengemukakan pendapat, menerima saran dan masukan dari peserta didik lain sehingga dapat meningkatkan hasil belajar peserta didik. Model pembelajaran MEA (Means-End Analysis) adalah pembelajaran yang memisahkan permasalahan yang diketahui (problem state) dan tujuan yang akan dicapai (goal state) yang kemudian dilanjutkan dengan melakukan berbagai cara untuk mereduksi perbedaan yang ada diantara permasalahan dan tujuan. Means berarti alat atau cara berbeda yang bisa memecahkan masalah, sementara ends berarti akhir tujuan dari 
masalah Nurafiah (2013). Hal ini sejalan dengan pendapat Huda (2013:294) bahwa MEA (Means-End Analysis) merupakan suatu model pembelajaran agar dapat menganalisis suatu permasalahan melalui berbagai cara yang dilakukan peserta didik untuk mencapai tujuan akhir yang diharapkan.

\section{KESIMPULAN}

Berdasarkan hasil penelitian tindakan kelas dilakukan dan pembahasan yang telah diuraikan, maka dapat disimpulkan bahwa model pembelajaran MEA (Means-End Analysis) berbantuan Schoology dapat meningkatkan hasil belajar peserta didik kelas XI SMA Negeri 1 Pekalongan Tahun Pelajaran 2018/2019. hasil belajar mengalami peningkatan dari prasurvei ke siklus I dimana pada prasurvei yaitu $31,82 \%$ menjadi $45,45 \%$ pada siklus I, peserta didik yang telah mencapai KKM mengalami peningkatan sebesar 13,63\%. Pada siklus II hasil belajar peserta didik meningkat dari Siklus I yaitu 45,45\% menjadi $95,45 \%$ pada siklus II, yang berarti peserta didik yang telah mencapai KKM mengalami peningkatan sebesar $50 \%$.

Berdasarkan hasil penelitian yang telah dilaksanakan dan kesimpulan yang telah dikemukakan, adapun saran yang diajukan peneliti sebagai berikut:

1) Guru dapat menerapkan model pembelajaran MEA (Means-End Analysis) berbantuan Schoology agar hasil belajar matematika menjadi lebih maksimal.

2) Guru hendaknya lebih meningkatkan perhatian dan mencurahkan segenap waktu untuk mengupdate materi dan tugas tugas di Schoology.

3) Diharapkan dapat memberi dukungan kepada guru untuk melaksanakan pembelajaran dengan model model pembelajaran MEA (Means-End Analysis) berbantuan Schoology

4) Memberi sarana yang mendukung peserta didik untuk lebih aktif dalam belajar berupa jaringan internet yang lancar.

\section{REFERENSI}

Aminoto, T \& Pathoni, H. 2014. Penerapan Media E-learning Berbasis Schoology Untuk Meningkatkan Aktivitas dan Hasil Belajar Materi Usaha dan Energi Di Kelas XI SMA N 10 Kota Jambi. Jurnal Sainmatika. Vol. 8, No. 1, hal. 13-29

Arikunto, S. (2013). Prosedur Penelitian Suatu Pendekatan Praktik. Jakarta: Rineka Cipta

Harto, K.T., dkk. (2014). Pengaruh Model Pembelajaran MEA dengan Setting Belajar Kelompok Berbantuan LKS Terhadap Hasil Belajar Matematika Siswa. E-jurnal Mimbar PGSD Universitas Pendidikan Ganesha (Online). Vol. 2, No. 1, Hal 1-10

Huda, M. (2014). Model-Model Pembelajaran. Yogyakarta: Pustaka Pelajar.

Juniyarti, N. (2014). Penerapan Model Pembelajaran Means End Analysis (MEA) Dalam Setting Di Untuk Meningkatkan Hasil Belajar Siswa. Berkala Ilmiah Pendidikan Fisika, Vol. 2, No. 3, hal. 204. https://doi.org/10.20527/bipf.v2i3.851

Mukhlason, A. (2019). Penerapan Model Means End Analysis Untuk Meningkatkan Hasil Belajar Siswa Materi Fluida. Jurnal Inovasi Pendidikan Fisika Dan Intograsinya. Vol. 2, No. 02. hal. 55-66

Murni, K., C. (2016). Pengaruh E-learning Berbasis Schoology Terhadap Peningkatan Hasil Belajar Siswa Dalam Materi Perangkat Keras Jaringan Kelas X Tkj 2 pada SMK Negeri 3 Buduran, Sidoarjo. It-Edu, Vol. 1, No. 01, hal. 86-90.

Nugroho, dkk. (2017). Penerapan Model Means Ends Analysis (Mea) Untuk Meningkatkan Kemampuan Menyelesaikan Soal Cerita Mata Pelajaran Matematika Pada Siswa Sekolah Dasar. Didaktika Dwija Indria, Vol. 5, No. 4 
Penerapan Pembelajaran MEA (Means-End Analysis) Berbantuan Schoology Untuk Meningkatkan Hasil Belajar Matematika

Satrio Wicaksono Sudarman ${ }^{1)}$, Nego Linuhung ${ }^{2)}$

Nurafiah, F., dkk. (2013). Perbandingan Peningkatan Kemampuan Berpikir Kritis Siswa SMP Antara yang Memperoleh Pembelajaran Means-Ends Analysis (MEA) dan Problem Based Learning (PBL). Jurnal Pengajaran MIPA (Online). Vol.18, No.1, hal. 1-8

Oktavia, L., A. dan Suprayitno. (2017). Penerapan Model Pembelajaran MEA (Means Ends Analysis) untuk Meningkatkan Kemampuan Berpikir Kritis Siswa pada Mata Pelajaran IPS Kelas IV SDN Simogirang 1 Prambon Sidoarjo. JPGSD. Vol. 5, No. 3, hal. 11581167

Pratiwi, A. D. (2016). Keefektifan Implementasi Model Pembelajaran Means-Ends Analysis Dengan Brainstorming Terhadap Hasil Belajar. Unnes Journal of Mathematics Education, 5(3), 173-181. https://doi.org/10.15294/ujme.v5i3.12553

Prihatiningtyas, N. C., \& Nurhayati, N. (2017). Penerapan Model Pembelajaran Means-Ends Analysis Untuk Meningkatkan Kemampuan Pemecahan Masalah Matematis Siswa. JPMI (Jurnal Pendidikan Matematika Indonesia), Vol. 2, No. 01, hal. 103. https://doi.org/10.26737/jpmi.v2i1.204

Purwaningsih, R. dkk. (2017). Pengaruh Penggunaan E-Learing Dengan Schoology Terhadap Hasil Belajar Peserta Didik. Jurnal Pembelajaran Fisika Universitas Lampung. Vol. 5, No. 4, hal. 51-61

Riana, A. A. (2017). Application of Means Ends Analysis (MEA) Learning Model in Attempt to Improve Student's High Order Thinking. International Journal Pedagogy of Social Studies, 2(1), 145. https://doi.org/10.17509/ijposs.v2i1.8688

Saraswati, D. (2018). Peningkatan Kemampuan Pemecahan Masalah Matematika Menggunakan Model Means Ends Analysis (MEA) Bagi Siswa Kelas 5 SD Sumogawe 02. Jurnal Pendidikan Dasar PerKhasa, 7(April), 1-25.

Sari, Y. N. 2018. Pengaruh Penerapan Model Pembelajaran Means Ends Analysis Menggunakan Media Video Terhadap Keaktifan Belajar Peserta Didik Pada Mata Pelajaran Ekonomi di SMA Negeri 3 Pagar Alam. Jurnal Profit. Vol. 5, No. 1, hal. 89104

Sukardi. 2012. Metode Penelitian Pendidikan Tindakan Kelas. Yogyakarta: Bumi Aksara.

Supratman, E., \& Purwaningtias, F. (2018). Pengembangan Media Pembelajaran E-learning Berbasis Schoology. Jurnal Informatika: Jurnal Pengembangan IT, Vol. 3, No. 03, hal. 310-315. https://doi.org/10.30591/jpit.v3i3.958

Suyatno. 2009. Menjelajah Pembelajaran Inovatif. Sidoarjo: Masmedia Buana Pusaka

Trianto. 2010. Model Pembelajaran Terpadu. Jakarta: Bumi Aksara.

Widiantoro, B., \& Rakhmawati, L. (2015). Pengembangan Media Pembelajaran E-learning Berbasis Schoology Pada Kompetensi Dasar Di SMKN 1 Jetis. Jurnal Pendidikan Teknik Elektro, Vol. 04, No. 2, hal. 501-506. 